\title{
Understanding the impacts of groundwater abstraction through long-term trends in water quality
}

\author{
Gejl, Ryle Nørskov; Rygaard, Martin; Henriksen, H. J.; Rasmussen, J.; Bjerg, Poul Løgstrup
}

Published in:

Water Research

Link to article, DOI:

10.1016/j.watres.2019.02.026

Publication date:

2019

Document Version

Peer reviewed version

Link back to DTU Orbit

\section{Citation (APA):}

Gejl, R. N., Rygaard, M., Henriksen, H. J., Rasmussen, J., \& Bjerg, P. L. (2019). Understanding the impacts of groundwater abstraction through long-term trends in water quality. Water Research, 156, 241-251. https://doi.org/10.1016/j.watres.2019.02.026

\section{General rights}

Copyright and moral rights for the publications made accessible in the public portal are retained by the authors and/or other copyright owners and it is a condition of accessing publications that users recognise and abide by the legal requirements associated with these rights.

- Users may download and print one copy of any publication from the public portal for the purpose of private study or research.

- You may not further distribute the material or use it for any profit-making activity or commercial gain

- You may freely distribute the URL identifying the publication in the public portal 


\section{trends in water quality}

3 Authors: Gejl, R.N. ${ }^{1,}{ }^{2}$, Rygaard, M. ${ }^{1}$, Henriksen, H.J. ${ }^{3}$, Rasmussen, J. ${ }^{2}$ and Bjerg, P.L. ${ }^{1}$

4 Institutions: DTU Environment ${ }^{1}$, HOFOR A/S ${ }^{2}$ and GEUS ${ }^{3}$

$5 \quad$ E-mail address: ryln@env.dtu.dk

Keywords:

- Sustainable groundwater abstraction

- Groundwater impact assessment

- Confined aquifer

- Groundwater quality

\section{Abstract}

It is vital to understand long-term trends in water quality parameters when assessing the sustainability of groundwater abstraction. Withdrawal-to-availability analysis is still used widely in groundwater management considering quantities and utilization rates based on in- and outflows. In this study, we took a step further than the water balance approach and carried out a detailed investigation of trends in longterm time series of groundwater quality, in order to analyze the sustainability of groundwater abstraction.

21 We assessed trends, links, and patterns in abstraction, potentiometric surface, and water quality parameters for 28 well fields around Copenhagen, Denmark. Groundwater monitoring data from 1900 until 2014 were investigated for each well field. During this period, the well fields experienced a 2 to $14 \mathrm{~m}$ decrease in the nearby potentiometric surface compared to the first-or pre-pumping-potentiometric 
surface recordings. Sulfate concentrations increased in 24 out of 27 well fields after the maximum abstraction period, compared to the earliest water quality measurements. The results indicate that in the 1980s, when water consumption (abstraction) and drawdown were at their highest, water abstraction caused a steady increase in sulfate and calcium, which we consider unsustainable. In contradiction, the abstraction in 24 well fields show almost steady sulfate levels in the aquifer after decreased water consumption since 1995. Only four well fields showed more than a $20 \mathrm{mg} / \mathrm{L}$ increase in sulfate concentration, which indicates that the recent abstraction does not interfere with sulfate levels in the aquifer. Our method and results show how long-term water quality trends can support the management of aquifer exploitation and evaluate sustainability on the well field scale.

\section{Introduction}

Groundwater is an important resource around the world (Gleeson et al., 2012; Margat and van der Gun, 2013), and some countries are entirely dependent on it for their water supply, for example Denmark. In spite of an increasing focus on the assessment of groundwater resources (Gejl et al., 2018; Gleeson et al., 2012), there is still potential for better representation of aquifer deterioration in terms of both groundwater levels and water quality. Such a quantification could ensure the efficient use of this vital resource and the management of future water availability (Li and Qian, 2018). Existing assessments of sustainable groundwater abstraction are usually based on a snapshot of the water cycle or by looking back over a few decades, which in many cases is too short a period for detecting long-term changes (Loftis, 1996). Long-term trends in aquifer drawdown have been investigated, but only by considering quantities in the water balance (Luczaj et al., 2017). Aquifers range from cave systems (Bauer-Gottwein et al., 2011), to fractured rock and limestone (Mosthaf et al., 2018) and unconsolidated, sedimentary deposits (Anderson et al., 2015). Each of these underground systems will respond differently to abstraction, and it is complex to provide predictions on the potential deterioration of the available groundwater resource due to water abstraction. Investigating the links between groundwater abstraction and its levels can help understand 
future aquifer responses to climatic and anthropogenic stresses and indicate a sustainable abstraction approach (Whittemore et al., 2016). We suggest that understanding long-term trends in quality can provide additional information for detailed investigations into aquifer sustainability and the management of groundwater resources.

Building upon the generic sustainability concept (Barnaby, 1987), groundwater abstraction can be considered sustainable when there is sufficient water for human and environmental needs, including for future generations. Furthermore, water abstraction is sustainable when there are no unacceptable impacts on levels, water quality, or environmental flow requirements (Henriksen and Refsgaard, 2013). However, besides rule of thumb values, there are no general accepted definitions of thresholds for acceptable utilization rates for different hydrogeological settings. Indicators take their starting point in water use (Boulay et al., 2017; Pfister et al., 2009), water scarcity (Smakhtin et al., 2004), groundwater footprint (Gleeson et al., 2012), or sustainable groundwater abstraction (Henriksen et al., 2008). These markers are well documented, easily communicated, and in general applicable to worldwide studies. Moreover, they are useful for screening purposes, given that they are based on precautionary principles; however, they are at the midpoint level for identifying environmental mechanisms (Bare et al., 2000) and do not deal with actual impacts or deterioration of the water resource itself. Some evaluations consider surface and groundwater as one resource, resulting in misleading effects for the latter's withdrawal (Gejl et al., 2018). Furthermore, the above-mentioned indicators are scoped mainly towards global or regional issues and they give little assistance to local challenges. We previously proposed a generic indicator aimed specifically at the local impacts of groundwater abstraction, which was applied to groundwater supply systems in Denmark (Gejl et al., 2018), but this indicator is also limited by the use of generic and globally utilized definitions of the water balance. In the following, we investigate the long-term effects of water abstraction on aquifer deterioration, by studying the relationships between abstraction, groundwater level and groundwater quality based on groundwater monitoring data for 28 well fields providing water to Copenhagen, Denmark, which have been influenced by abstraction for decades. 
We focused on confined aquifers as a typical and important example for worldwide groundwater use.

Abstracting water from a confined aquifer will reduce the potentiometric surface (hydrostatic pressure) and induce a change in local vertical gradients that can accelerate groundwater recharge. In turn, these changed gradients will influence the velocities and directions of water flow in the groundwater system. The abstraction-induced decrease of the potentiometric surface can affect water quality in two ways: 1) It can change water quality, as a result of drawing water from one or several sources; and 2) it can influence groundwater processes, again with the same result. Our hypothesis is that an overexploited groundwater system, over time, will tend to undergo deteriorating water quality depending on the geology, the groundwater system, and the well specifications. A continuous change for the worse in water quality parameters indicates unsustainable abstraction, in which case there is a risk that the water quality with time will become unsuitable for drinking water supply.

We wanted to investigate what defines sustainable groundwater abstraction in terms of potentiometric surface and groundwater quality, thereby augmenting the volume-based sustainability assessment. Trends in water quality parameters have been used for many years to assess groundwater withdrawal and provide indications of issues such as pyrite oxidation (Andersen et al., 2001), saltwater intrusion (Bryan et al., 2016), and nitrate contamination (Schullehner et al., 2018). Many studies have looked into the details of chemical responses and specific processes governing local water quality (e.g. Jessen et al., 2016; Larsen and Postma, 1997), whereas our aim was to investigate overall trends across many well fields. From changes in water quality, we can propose limits to groundwater abstraction that would serve as one criterion among others to assess a sustainable abstraction. The study aimed to:

- Investigate how abstraction affects the potentiometric surface in the aquifers

- Identify which groundwater processes and parameters were affected by abstraction in the studied well fields 
- Evaluate long-term patterns in potentiometric surface and water quality parameters across multiple well fields

- Explore if groundwater quality parameters can serve as indicators for sustainable groundwater abstraction

\section{Aquifer systems and water quality}

\subsection{Water abstraction and hydraulic gradients}

Aquifers can be classified as either confined or unconfined. When low permeability layers separate aquifers, these are termed "confined," and otherwise "unconfined" (Appelo and Postma, 2005; Freeze and Cherry, 1979). Confined aquifers with a potentiometric surface higher than the confining layer are especially relevant for water supply, due to their protection from surface contaminants (Trowsdale and Lerner, 2003), and constitute the aquifers we study in this paper.

Before abstraction (pre-pumping conditions), the potentiometric surfaces in different aquifers at different depths are in balance, and there will typically be a downward flow due to the difference in head (Figure 1.a). Inducing abstraction from a deep aquifer will change its potentiometric surface, and to a lesser degree the potentiometric surface in the upper aquifer, thereby increasing the hydraulic gradient (Figure 1.b). Hence, we can use this change in the deep aquifer's potentiometric surface as a proxy for the vertical gradient. The change in hydraulic gradient influences the flow direction, and so water may be drawn down, up, or in from the sides. "New" water drawn into the aquifer can have another chemical composition or influence processes that affect groundwater quality.

\subsection{Water quality parameters affected by water abstraction}

A changed water influx or shift in redox conditions can change a number of water quality parameters, depending on the geology, hydrogeology, and biogeochemical processes in and around the aquifer. In our case, it is relevant to focus on the following water quality parameters: chloride, sulfate, calcium, 
magnesium, and sodium. Nitrogen in various forms is used as fertilizer and can cause nitrate

121

122

123

124

125

126 contamination, which is a concern for many water supplies (Hansen et al., 2012, 2011; He and Wu, 2018) and arsenic is a challenge for water supply around the world (Nordstrom, 2002). Nitrate and arsenic is not the main focus of this study, because the concentrations were low or without a clear pattern for the well fields (see assessment in section 3). Furthermore, the measurement period for arsenic was too short to detect long-term changes, however, for both arsenic and nitrate the presence and involvement in biogeochemical processes have been assessed (see next section).

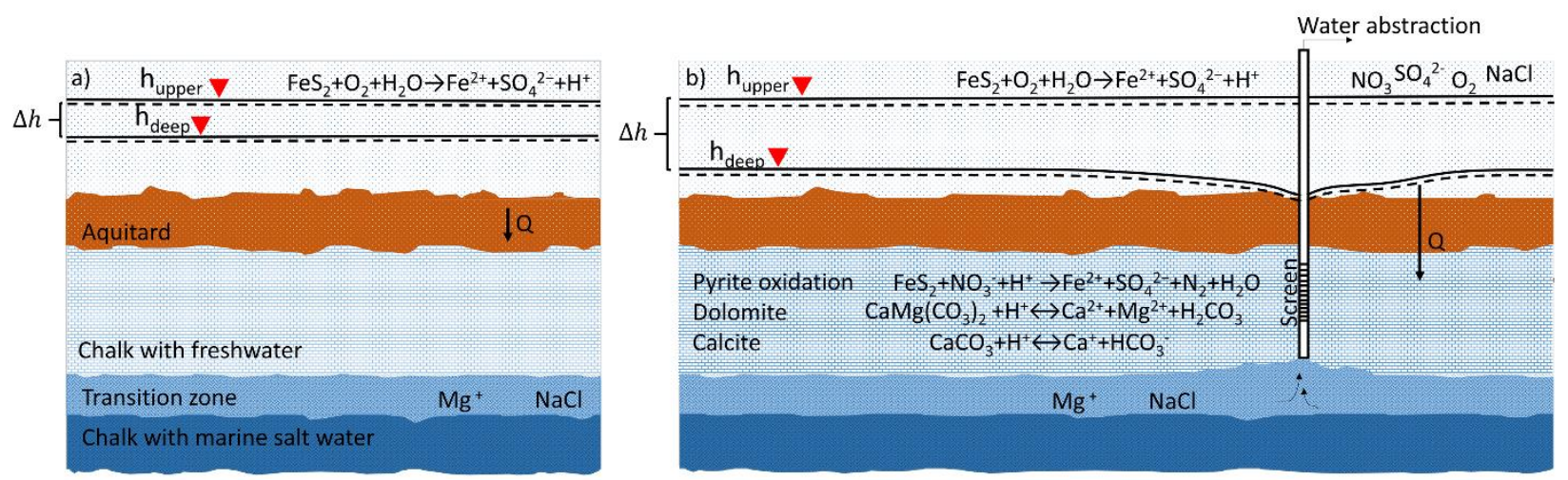

Figure 1: A conceptual figure of potential changes in a typical Danish confined aquifer resulting from abstraction. a)

Before abstraction (pre-pumping conditions) and b) during abstraction. $h_{\text {deep }}$ and $h_{\text {upper refer to the potentiometric surface }}$ in the deep and the upper aquifer, respectively. $Q$ is groundwater flow, and the length of the arrow indicates the gradient difference. Modified from Vangkilde-Pedersen et al. (2011).

\subsection{Processes affecting water quality}

Changing from reduced to oxidized conditions will affect water quality. In Denmark, the oxidation of pyrite is a primary concern, as it produces sulfate, iron precipitates, acid, and sometimes releases nickel and arsenic (Appelo and Postma, 2005; Postma et al., 2007). Pyrite is abundant in certain sand deposits (Jensen et al., 2003) and the limestone (Jakobsen et al., 2017; Knudsen, 1999) and a reduced potentiometric surface or transportation of dissolved oxidizers, such as oxygen or nitrate, to the saturated zone may lead to pyrite oxidation. The acid produced as a result may dissolve calcium carbonate from calcareous or chalk aquifers, which can correlate with the sulfate concentration (Vangkilde-Pedersen et al., 2011). 
The background concentration of sulfate in groundwater in Denmark ranges from 10 to $30 \mathrm{mg} / \mathrm{L}$, depending on the atmospheric concentration of sulfur in precipitation (Hansen et al., 2009), but it may be lower in reduced conditions (Miao et al., 2013). Pyrite oxidation is often caused by oxygen and/or nitrate, which is controlled and determined by different processes (SI. A)). Where nitrate is generated from fertilizers and the concentration will depend on the application, oxygen can come in 1) gaseous form in leaking aquifers or from improper wells (Baba and Ayyildiz, 2006) or in 2) dissolved form with the groundwater recharge, however the latter is often proportionally small compared to the first.

There are several other important aspects and processes affecting groundwater quality, such as saltwater intrusion and other dissolution/precipitation processes than the one related to pyrite oxidation, but these are of minor importance in terms of the results in this study and are not discussed further. There were also indications of ion exchange and reverse ion exchange processes at the well fields, but there were no clear patterns or links to abstraction as discussed later.

\section{Methods: Abstraction, potentiometric surface, and water quality}

153 The Danish capital city, Copenhagen, currently receives water from 51 well fields located up to $40 \mathrm{~km}$ from

154 the city (Figure 2). The typical hydrological conditions on Zealand consist of layers of sand and clay and the 155 chalk, from which the majority of the drinking water is abstracted (Figure 2.c). The Greater Copenhagen

156 Utility (HOFOR) has supplied water to Copenhagen since 1859 and is now providing 50 million $\mathrm{m}^{3}$ water per 157 year for 1 million inhabitants. HOFOR provided our study with groundwater level datasets starting in 1900, 158 with several measurements of the potentiometric surface per year, and close to annual samples of a range of groundwater quality parameters since 1940. 
Well fields supplying Copenhagen

- Hørup and Marbjerg well fields

a) $\quad$ Well fields managed by HOFOR
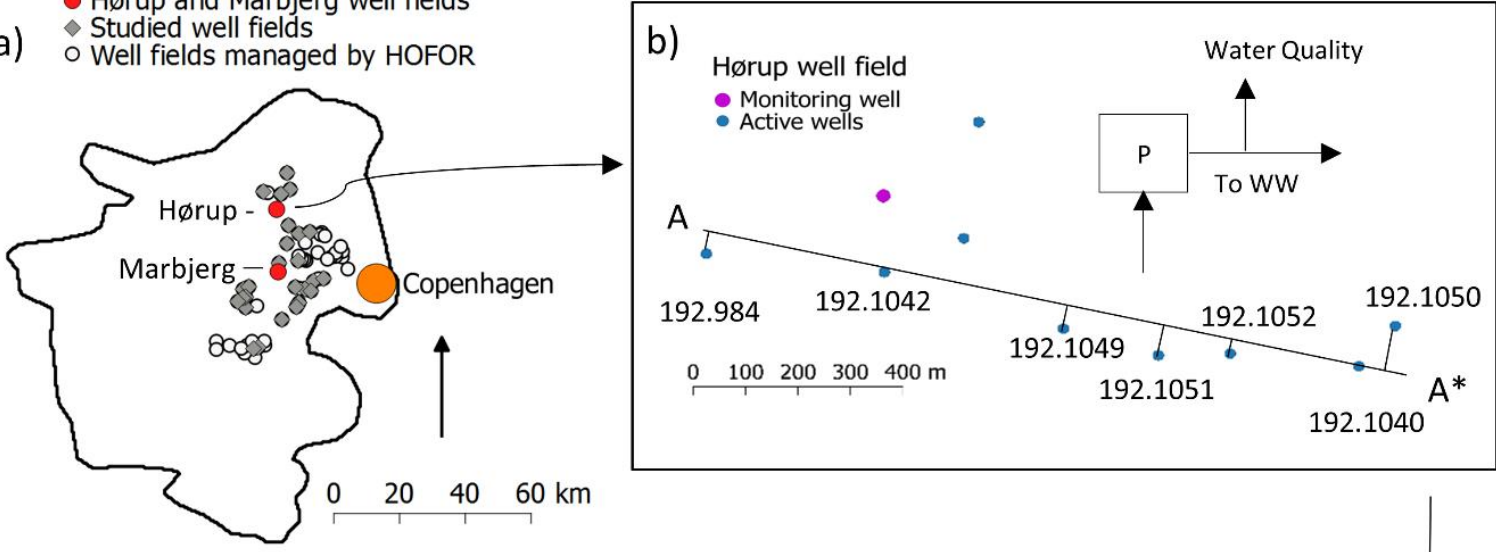

c) $\mathrm{A}$

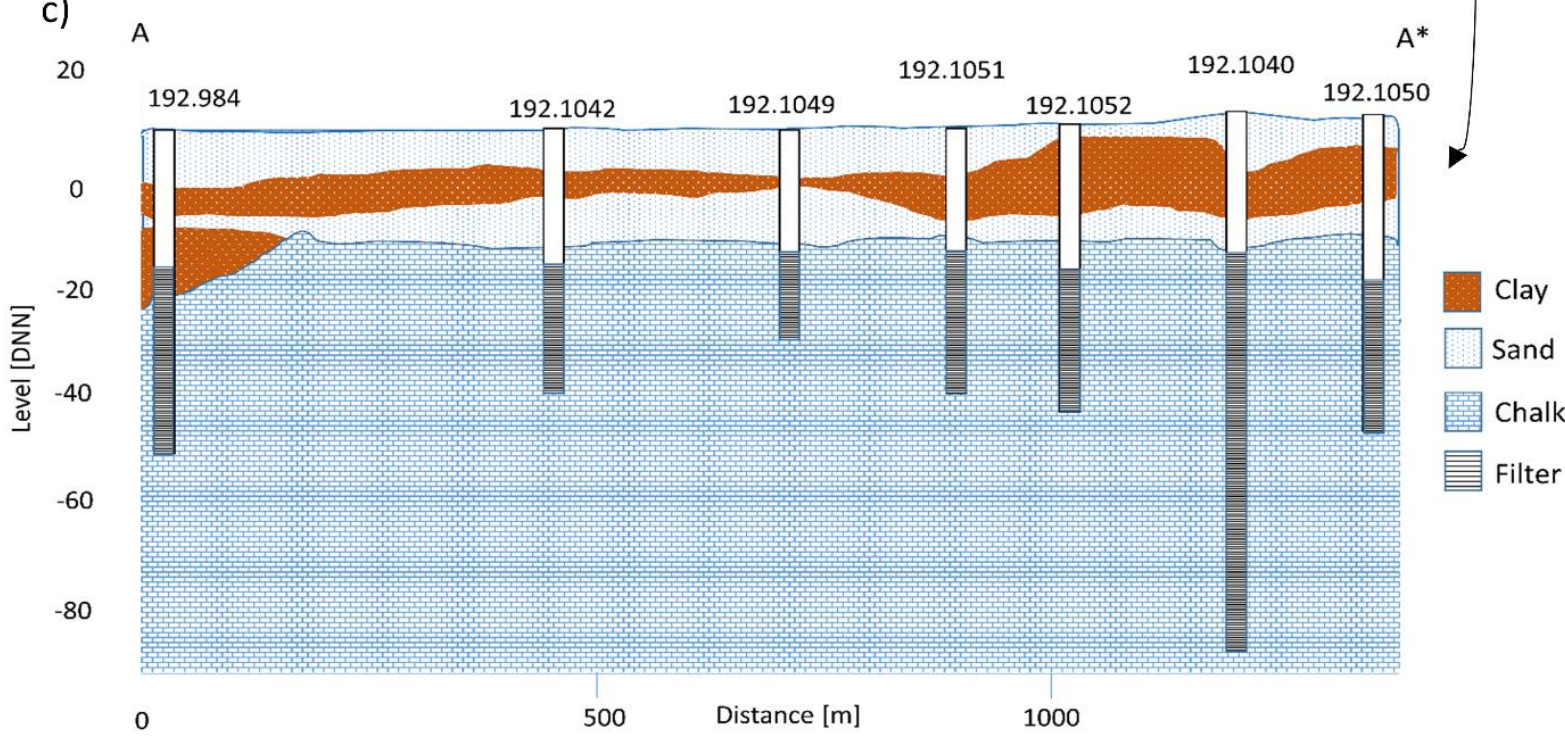

0

500

Distance $[\mathrm{m}]$

Figure

161 2: a) HOFOR's well fields at Zealand, Denmark. The well fields included in this study are marked with gray squares, and

all of those managed by HOFOR are marked with white circles. b) A close-up of Horup as an example of a typical well

field and c) a geologic profile of some of the wells at Hørup well field. Well fields in HOFOR typically consist of multiple wells 'on a string'. $P$ is the pump collecting water from all of the wells before pumping it to the waterworks (WW). Water quality samples are collected downstream of all wells before any treatment at the waterworks.

To find the link between abstraction and the potentiometric surface, we assessed the combined abstraction

for each well field and the local drawdown in a monitoring well close to each site (Figure 2b).

168 All water quality samples used for our analysis were collected from the water mix downstream of all wells and before any treatment (Figure 2b). Historically, groundwater abstraction was monitored at waterworks and not at the individual well field, which means that for most well fields we only had data starting after 
the actual abstraction started. In the majority of cases, we do not know the size of water abstraction that led to the initial decrease in the potentiometric surface and a change in water quality.

HOFOR has 51 well fields that are active or have been active recently, and we made a selection for further study based on the following criteria:

- Continuous data; well fields with a maximum 10-year gap in data and abstraction.

- Long time series; well fields that started abstracting water before 1970 and have been active for more than 30 years.

- No major changes within the well field, e.g. moving the well field, so that changes in water quality is due to the change of location. This was based on expert judgement by HOFOR.

- Individual data; abstraction and water quality data for each well field.

The criteria led to the selection of 28 out of 51 well fields for further analysis (Table 1). All well fields and the reason for their inclusion/exclusion are listed in supporting information B (SI.). We obtained data on water abstraction, potentiometric surface, and water quality for the well fields. Many of the sites lacked early data on abstraction, so we found approximate years for its initiation, through historic waterworks reports. Potentiometric surface measurements was obtained from monitoring wells chosen by their proximity to the well field and expected minimum influence from other well fields (the ID numbers of the monitoring wells can be found in SI. C). The distance between the monitoring well and well field was taken from the monitoring well to the center of the well field, which itself was found by polygon centroids in QGIS from the well field area given by HOFOR.

The final dataset consisted of 3,389 samples of water quality analyses for 28 well fields dating from 1940 to 2015 , resulting in 20,330 datum of water quality parameters. There were 1,458 yearly abstraction observations for the 28 well fields and more than 10,000 water level measurements dating from 1900 to 2017. The data were analyzed in different ways, in order to understand links between abstraction, 
potentiometric surface, and water quality. Firstly, we compared water quality for the first five water quality samples (referred to as the "first period") with the five-year period of maximum known abstraction (referred to as the "maximum abstraction period") and the period of the last five water quality samples 197 (referred to as the "last period"). The first period is our best representation of pre-pumping water quality in the aquifer before it is impacted by groundwater abstraction, however, for some of the well fields the first period actually represent an aquifer already impacted by pumping. The parameters were presented as absolute changes, to overcome misleading results from comparing increased concentrations from small numbers or zero values. Secondly, the data were plotted as time series, to show trends and changes in potentiometric surface and water quality. Thirdly, correlations between observed parameters were found with a two-sample t-test (the statistical significance is evaluated for $\alpha=0.05$ ). Besides the comparison of 204 different periods, we have used the initial (first) measurement of potentiometric surface to evaluate the 205 drawdown, since the potentiometric surface is rapidly responding to abstraction. 

well is the distance from the center of the well field to the observation well. Abs. is an abbreviation for abstraction. 


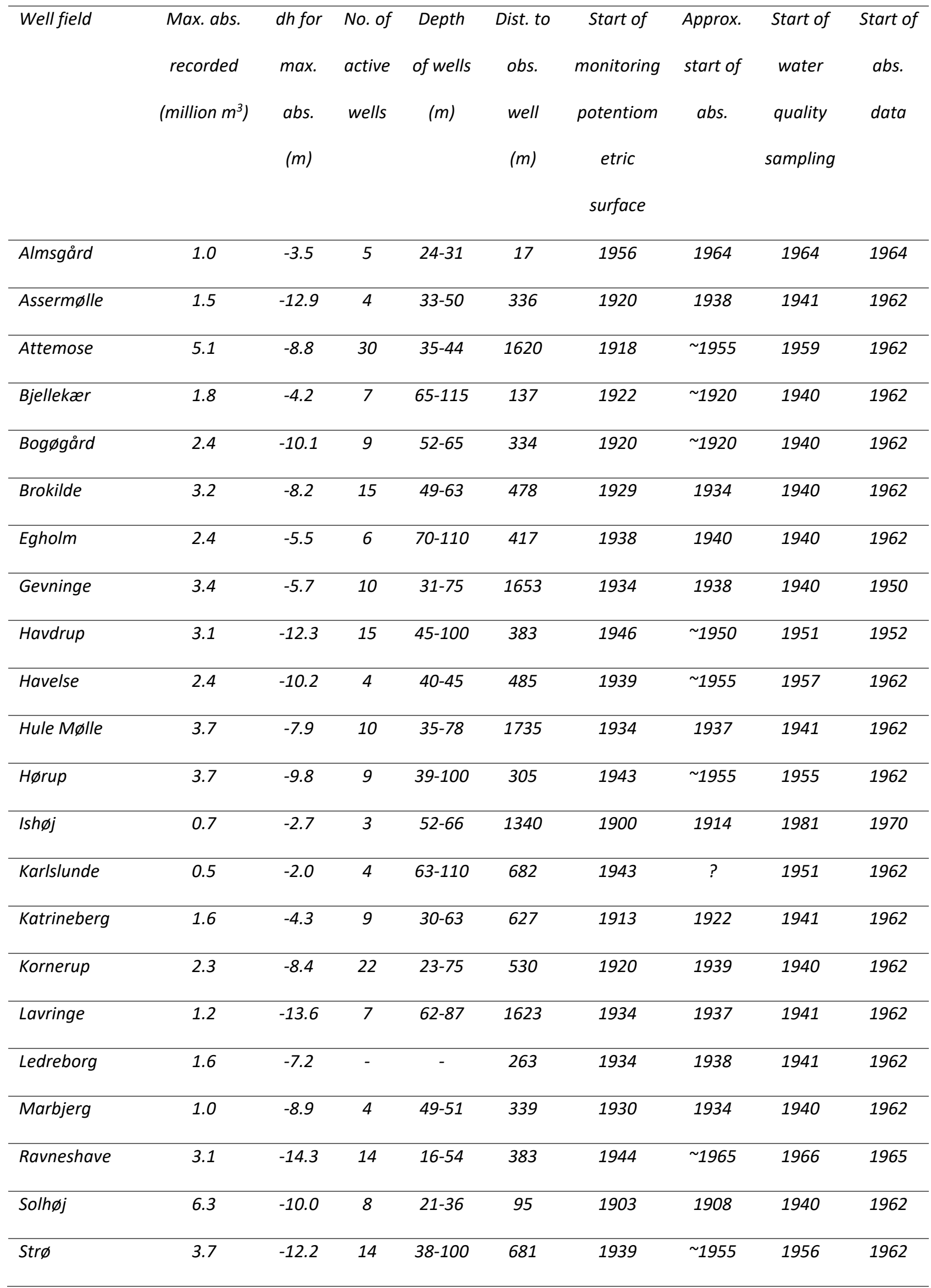




\begin{tabular}{lccccccccc}
\hline Thorsbro & 3.5 & 5.5 & 19 & $12-54$ & 67 & 1909 & 1908 & 1941 & 1981 \\
\hline Tåstrup Valby & 1.6 & 3.7 & 7 & $12-30$ & 276 & 1945 & 1919 & 1940 & 1962 \\
& & & & & & & & & \\
\hline Vallensbæk & 0.5 & 5.1 & - & - & 406 & 1943 & 1948 & 1951 & 1962 \\
\hline Vardegård & 1.2 & 6.1 & - & - & 543 & 1939 & 1948 & 1951 & 1962 \\
\hline Værebro & 3.6 & 2.9 & 13 & $34-75$ & 712 & 1943 & 1950 & 1951 & 1962 \\
\hline AEbelholt & 2.3 & -10.4 & 6 & $60-120$ & 1273 & 1915 & $\sim 1955$ & 1961 & 1962
\end{tabular}

210 When the water quality sampling started in the 1940s, the water abstraction for Copenhagen was greater

211 than it is now. Furthermore, for the majority of well fields' (24) water was withdrawn for some time before

212 initiating data on abstraction quantities and water quality, and therefore we cannot observe the

213 development from pre-pumping. We excluded some water quality parameters, because we were interested

214 in water quality parameters that consistently responded to groundwater abstraction (Table 2).

215 Table 2: Water quality parameters excluded from further analysis

\section{Water quality parameters Reason for exclusion from analysis}

pH

Little development in $\mathrm{pH}$

Nitrate

No clear connection to abstraction

Only 8 out of 28 well fields had a nitrate concentration above $10 \mathrm{mg} / \mathrm{L}$

(SI. I)

Maximum concentration of $28 \mathrm{mg} / \mathrm{L}$

Hydrogen Carbonate

Cobalt

Short measurements periods $(>1990)$

No clear connection to abstraction 
Generally little development in concentration

Iron $\quad$ Small concentration $(<6 \mathrm{mg} / \mathrm{L})$

Generally little development in concentration

Magnesium No clear connection to abstraction

Nickel Short measurements periods $(>1990)$

Only four well fields have concentrations $>20 \mu \mathrm{g} / \mathrm{L}$

No clear connection to abstraction

Generally little development in concentration

Arsenic

Only one well field had a concentration $>5 \mu \mathrm{g} / \mathrm{L}$ for a four year period

(SI. I)

No clear connection to abstraction

\section{Results \& Discussion}

\subsection{Long-term abstraction and water level}

218 We compared average concentrations of water quality parameters and potentiometric surfaces for the two

219 periods: The maximum abstraction period and the first period (Table 2). The comparison was only 220 applicable for 27 well fields, because for one well field (Ishøj) the first period and the maximum abstraction 221 period were the same periods. In 23 out of the 27 well fields, the potentiometric surface decreased 222 between the two periods (Table 2). For 24 well fields, abstraction volume observations started more than 5 223 years after data collection- and water quality sampling started, which is probably the reason for the 
224 increased potentiometric surface at four well fields (Table 2). However, when comparing potentiometric

225 surface for maximum abstraction with the initial potentiometric surface, there was a drawdown for all 28

226 well fields (Table 1). In spite of large variations, the changes in potentiometric surface and abstraction

227 showed a statistically significant correlation (Figure 3).

228 Table 3: Changes in parameters between the first period and the maximum abstraction period. Changes in water quality 229 greater than $0,5,20$, and $60 \mathrm{mg} / \mathrm{L}$ resulted in,,++++++ , and ++++ , respectively, for increases and -, --, ---, and ---230 respectively for decreases. For changes in drawdown (dh) greater than 0, 1, 2, and $6 \mathrm{~m}$ were assigned +, ++, +++, and $231++++$, respectively, for increases and -, --, ---, and ----, respectively, for decreases. n.a. was a well field where the first 232 period and the maximum abstraction period were the same period. 0 was no measured difference between the periods. 233 No. of years between periods is the difference between the first year in each period. 


\begin{tabular}{|c|c|c|c|c|c|c|c|}
\hline Well field & $\begin{array}{c}\text { No of years } \\
\text { between period }\end{array}$ & $d h(m)$ & Chloride & Sulfate & Calcium & Magnesium & Sodium \\
\hline Almsgård & 15 & ++ & ---- & ++++ & +++ & -- & ---- \\
\hline Assermølle & 56 & +++ & --- & ++ & +++ & ++ & ---- \\
\hline Attemose & 4 & ++ & + & + & + & + & - \\
\hline Bjellekær & 38 & +++ & + & +++ & ++ & + & -- \\
\hline Bogøgård & 28 & ++++ & --- & +++ & ++ & + & --- \\
\hline Brokilde & 46 & +++ & - & +++ & ++ & + & + \\
\hline Egholm & 22 & ++ & -- & ++++ & +++ & + & - \\
\hline Gevninge & 39 & +++ & ++++ & ++++ & ++ & + & ++++ \\
\hline Havdrup & 6 & +++ & ++ & --- & - & - & - \\
\hline Havelse & 43 & + & - & ++ & ++ & ++ & - \\
\hline Hule Mølle & 28 & ++ & - & +++ & ++ & 0 & -- \\
\hline Hørup & 8 & ++++ & - & +++ & +++ & + & - \\
\hline Ishøj & 0 & n.a. & n.a. & n.a. & n.a. & n.a. & n.a. \\
\hline Karlslunde & 34 & - & - & +++ & ++ & + & -- \\
\hline Katrineberg & 22 & - & + & ++ & ++ & ++ & - \\
\hline Kornerup & 27 & +++ & ++ & +++ & +++ & ++ & --- \\
\hline Lavringe & 30 & ++ & - & ++ & ++ & -- & + \\
\hline Ledreborg & 37 & + & --- & ++++ & +++ & -- & --- \\
\hline Marbjerg & 22 & +++ & - & ++ & ++ & - & - \\
\hline Ravneshave & 16 & +++ & --- & ++++ & +++ & - & -- \\
\hline Solhøj & 46 & ++ & ++ & +++ & +++ & + & - \\
\hline Strø & 7 & +++ & + & +++ & ++ & ++ & - \\
\hline
\end{tabular}




\begin{tabular}{lccccccc}
\hline Thorsbro & 46 & - & ++ & ++++ & +++ & + & + \\
\hline Tåstrup Valby & 23 & ++ & + & ++ & ++ & + & - \\
\hline Vallensbæk & 28 & + & +++ & ++++ & +++ & ++ & - \\
\hline Vardegård & 29 & --- & + & ++ & - & + & -- \\
\hline Værebro & 11 & + & + & ++ & ++ & + & -- \\
\hline AEbelholt & 6 & +++ & + & 0 & - & + & +
\end{tabular}

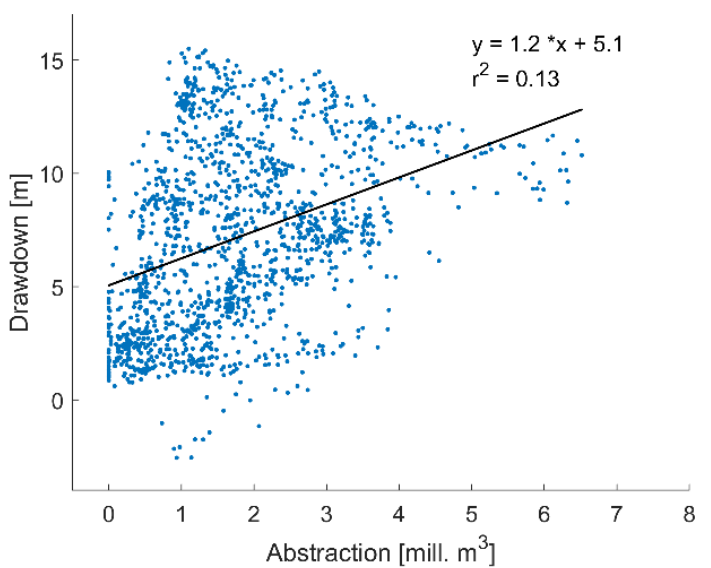

Figure 3: Correlation between yearly observations of drawdown from initial potentiometric surface and abstraction for 28 237 well fields.

238 The well fields responded differently to abstraction, with decreased potentiometric surfaces from 2 to $14 \mathrm{~m}$ 239 from the first observation to the average of the maximum abstraction period (Table 1). The correlation 240 between abstraction and change in the potentiometric surface (Figure. 3) is significant despite large variations, such as a drawdown for the maximum abstraction period of $14 \mathrm{~m}$ for abstracting $1.2 \mathrm{mill} \mathrm{m}^{3}$ of water from Lavringe well field and a drawdown of $6 \mathrm{~m}$ for a similar withdrawal at Vardegård well field

243 (Table 1). There are a few negative drawdowns, which means that the potentiometric surface is higher compared to the first registered potentiometric surface. These levels of potentiometric surface are relatively recent potentiometric surface observations from Thorsbro well field (SI. D), most likely because the initial potentiometric surface does not represent pre-pumping conditions. 
Sulfate concentrations increased for 25 out of the 27 well fields (except Havdrup and Ebelholt well fields) and by more than $20 \mathrm{mg} / \mathrm{L}$ for 16 out of 27 well fields (Table 2). Calcium concentrations increased at 24 out of 27 well fields, with increases at similar sites that experience increased sulfate concentrations, except for Vardegård. This was expected, since both parameters are affected by pyrite oxidation (Appelo and Postma, 2005). Chloride concentrations increased at 14 well fields and decreased at 13 showing that an abstraction will mobilize new water-sometimes from the saline transition zone, and sometimes younger, fresher water as also reported in Appelo, (1994). Sodium decreased at 22 out of the 27 well fields, thus supporting the notion that saltwater mobilization is not a widespread problem for these well fields, albeit Gevninge well field experienced substantial increases in sodium and chloride, indicating saltwater mobilization. Magnesium concentration increased at 20 out of 27 well fields.

Changes in sulfate concentration varied between the well fields, ranging from -20 to $172 \mathrm{mg} / \mathrm{L}$, with an average of $48 \mathrm{mg} / \mathrm{L}$ when comparing the first period with the maximum abstraction period (SI. E). Due to a delayed response in sulfate, these periods do not show its maximum concentration (SI. D). Havdrup well field (as one of two well fields) saw a decreased sulfate concentration, which we speculated was due to an initial freshening of the aquifer and a subsequent delayed sulfate response. Havdrup experienced an increase in sulfate concentration over time (see SI. D). This was not captured in Table 2, because the periods compared are chronologically close, and therefore the sulfate did not respond fully to the change in the hydraulic gradient (Table 2). At Æbelholt well field, there are still reduced conditions, and the sulfate concentration is between $0-17 \mathrm{mg} / \mathrm{L}$ throughout the analysis period.

267 The results in Table 2 highlight links between changes in hydraulic gradients and changes in water quality, most noticeably for sulfate. The absolute concentrations for the two periods and the last period are illustrated in SI. E. 
270 We performed paired correlations of all parameters for yearly observations and for a 20-year delay in water

271 quality parameters compared to the potentiometric surface (SI. F). The correlations are not used further in

272 this study, since processes and drivers (stressors) other than abstraction might affect them, and this was

273 beyond the scope of this article.

\section{$274 \quad$ 4.2 The relationship between groundwater quality and potentiometric surface drawdown}

275 Long-term changes in abstraction, potentiometric surface and four water quality parameters for two typical

276 well fields showed links between potentiometric surface and water quality limits (Figure 4). One of the well

277 fields, Hørup, had a typical abstraction pattern with high withdrawals before 1995, and lower thereafter.

278 The potentiometric surface showed a response to the abstraction without too much fluctuation. Since the

279 water quality data started approximately with initiating water abstraction, we expected to observe a

280 development in water quality from the beginning of the process. Marbjerg well field has been active since

281 1934, and therefore we expected to be able to observe late responses in terms of long-term abstraction.

282 Long-term trends for all 28 well fields are detailed in SI. D. 

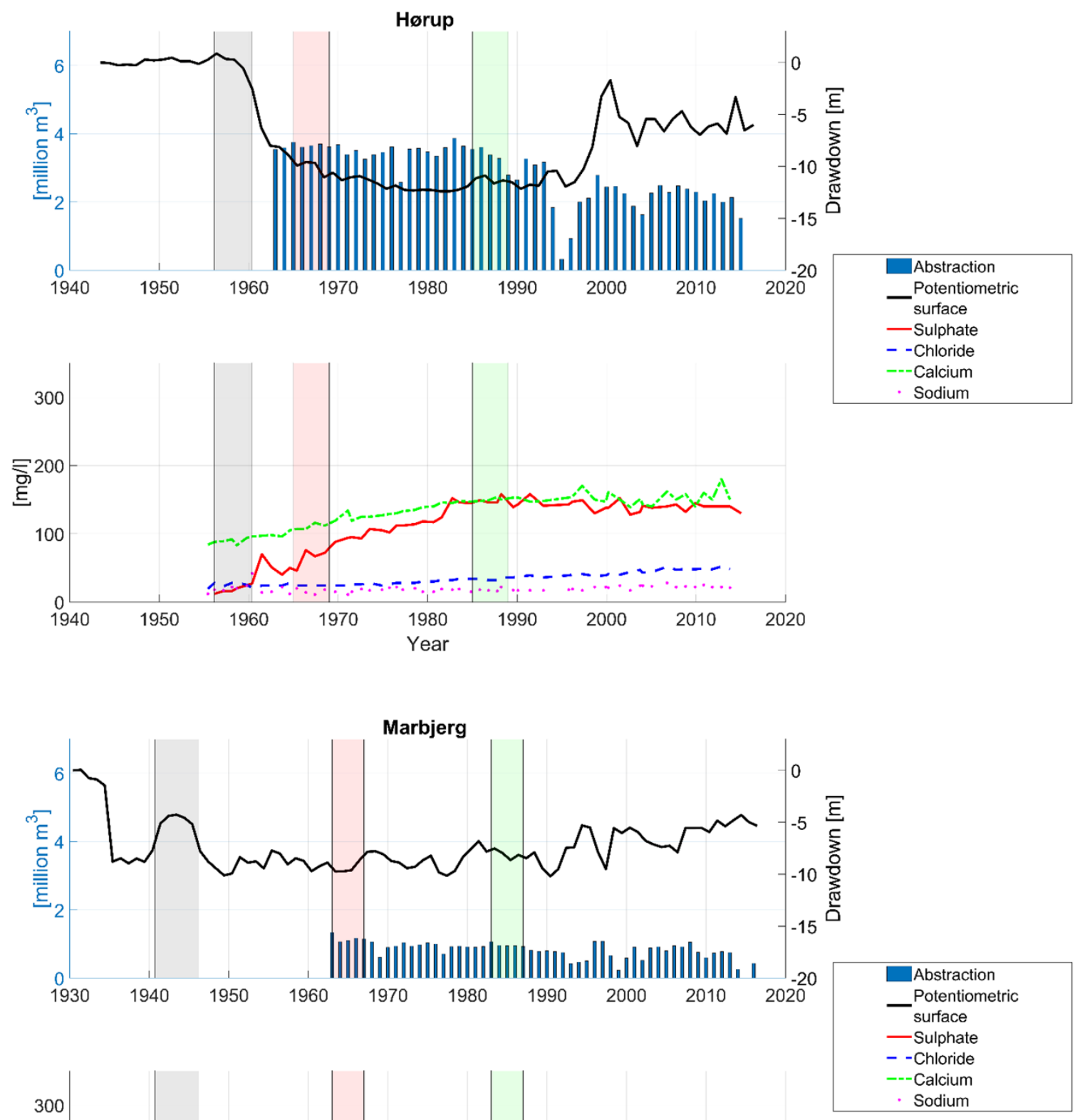

Figure 4: Water quality parameters, such as sulfate, chloride, calcium, and sodium, plotted with the potentiometric surface and abstraction for Hørup and Marbjerg well fields. The hatched areas refer to the periods compared herein: grey marks the first period, red marks the maximum abstraction period, and green marks 20 years after the maximum abstraction period. 
The potentiometric surface at $\mathrm{H} \varnothing$ rup well field seemed to respond directly to abstraction; when the water abstraction was high, the potentiometric surface was low, and when the water abstraction decreased, the potentiometric surface stabilized at a higher level. We did not have access to data of water abstraction that lead to the initial decrease in the potentiometric surface around 1956. At the start of water quality sampling in 1955, sulfate concentration was $15 \mathrm{mg} / \mathrm{L}$ and it increased until around 1982, when it stabilized, followed by a slight decrease from around 1997. Sulfate concentration ended at approximately $140 \mathrm{mg} / \mathrm{L}$, which is 10 times the initial concentration. Chloride concentration increased steadily over the whole period, from 25 to $50 \mathrm{mg} / \mathrm{L}$ in 2014. Marbjerg well field had larger fluctuations in potentiometric surface, and so it might have had another abstraction management or been affected by climate and other factors. The potentiometric surface dropped around 1934 and increased from 1941-1944 (probably due to a pause in abstraction, maybe related to the 2 . World War). Sulfate concentration initially decreased, either due to a change in water composition or because of processes related to the increase in the potentiometric surface. The final concentration was $71 \mathrm{mg} / \mathrm{L}$, which was twice the concentration of the first period. The potentiometric surface increased from 1990 and the sulfate concentration slightly decreased from 1993. Similarly to $\mathrm{H} \varnothing$ rup, chloride concentration increased steadily over the whole period, albeit only by $13 \%$.

\subsection{Potentiometric surface and sulfate}

From Table 2, we observed indications of a link between drawdown and sulfate concentrations. The correlation between the drawdown for the maximum abstraction period and the sulfate concentration 20 years thereafter is statistically significant in spite of variations, which supports the hypothesis that sulfate increases with a decreasing potentiometric surface (Figure 5). Despite the large spread in points the data can be represented by the fitted line (statistical significant for $\alpha=95 \%)$. Egholm well field was an outlier and we expected two possible reasons for this 1) the initial potentiometric surface did not represent prepumping conditions and therefore the measured drawdown was relatively small or 2) that it is a leaky aquifer or only partly protected by an impermeable layer. Since we cannot exclude Egholm well field, it is included in the t-test. Evaluating the residuals (SI. G), we see that our data are not independent and 
313 identically distributed, and therefore not well represented by a linear regression. We expect that the

314 impacts from drawdown on water quality will decrease with increasing drawdown, however for larger

315 drawdowns than represented in our data. Therefore we believe that a linear correlation is the best

316 explanation and we did not find a significant improvement of fit from transforming the data.

317 Since drawdown was measured in a monitoring well at a given distance from the well field (Table 1), we

318 expected that monitoring wells far away from the well field would have a smaller drawdown compared to if

319 the well field was located closer. If the actual drawdown close to the well field result in increased sulfate

320 concentrations, this could be hidden by a relatively small drawdown in a remote monitoring well. However,

321 the distance from center of the well field to the monitoring well does not clearly affect changes in sulfate

322 (Figure 5), and does not improve the statistical significance albeit well fields with distances greater than 800

$323 \mathrm{~m}$ between the center of the well field to the monitoring well are all below the regression line. The two well

324 fields with the smallest changes in sulfate concentration (and relative large distance between center of well

325 field and monitoring well between 800 to $1600 \mathrm{~m}$ ) are Attemose and ÆEbelholt well fields. Attemose well

326 field have a low change in sulfate because there are few years between the periods compared. Ebelholt

327 well field have a steady sulfate concentration throughout the period and continuously reduced conditions

328 with a sulfate concentration of $2 \mathrm{mg} / \mathrm{L}$ for the last period for further statistical analysis of the data see SI. G. 


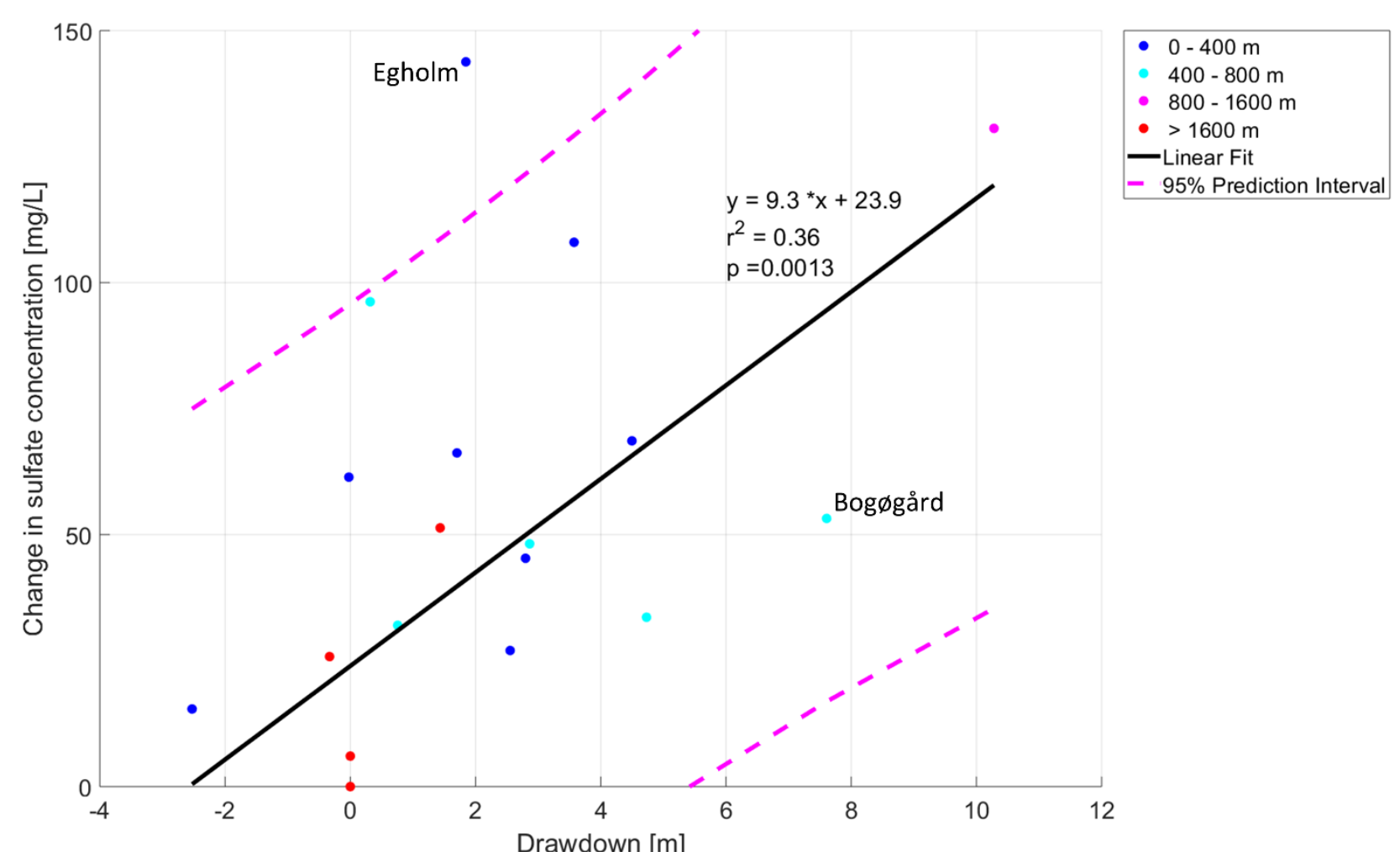

Figure 5: Linear Fit of correlation between drawdown and changes in sulfate concentration with 20-years delay for sulfate for 26 well fields including 95\% Prediction Interval. Drawdown was compared from the first period and the maximum abstraction period. The change in sulfate concentration was compared between the first period and 20 years after maximum abstraction. The colors of the dots represent the distance between the center of the well field and the monitoring well.

335 There were large differences in the delay periods of sulfate concentration as a response to abstraction.

336 Studying the development of sulfate concentration over time in SI. D, it is evident that for some well fields

337 the sulfate peaked at the same time as the abstraction peaked (e.g. Ravneshave well fields), whereas other

338 well fields responded slower (e.g. Havelse well field). Several factors influence water quality at individual

339 well fields, and so it is relevant to study further how delay-times affect sulfate concentrations. For 13 out of

340 the 26 well fields, sulfate concentrations were higher for the last period compared with the maximum

341 abstraction period, for seven well fields it was lower, and for six it changed by less than $10 \%$. However,

342 among $0,5,10,15$ and 20 years' delay, the best correlation between drawdown and sulfate concentration

343 was found 20 years after the maximum abstraction (Figure 5, SI. H). There linear fit only represents 26 well

344 fields, because for two of the well fields the maximum abstraction is less than 20 years before the last

345 water quality samples. 
Long-term trends in the water quality parameters excluded from this study can be found in SI. I. These water quality parameters were excluded, because the data did not show developments in concentration, the concentrations were generally low or the data period too short, to detect development or a connection to drawdown (Table 2). We had expected that arsenic and sulfate concentrations would be correlated (e.g. Zhang et al., 2013), however arsenic concentrations were low, with only one well field with concentrations above $5 \mu \mathrm{g} / \mathrm{L}$, which looks like outliers (Egholm well field). A Danish study finds relatively little arsenic in the groundwater around Copenhagen, however there are larger concentrations in other parts of Zealand (Larsen and Kjøller, 2009). Similarly, a relation between sulfate and nitrate has been reported in literature (Jørgensen et al., 2009; Zhang et al., 2013), however, nitrate concentrations were low at most well fields

(only 8 out of 28 well fields had concentrations above $10 \mathrm{mg} / \mathrm{L}$ ). Since nitrate is an oxidizer in pyrite oxidation the relative high sulfate concentrations are in good coherence with the relatively low nitrate concentrations.

\subsection{Water quality variations within the well fields}

Water quality is more complex than appears from samples of combined water taken from a well field, and therefore we cannot expect all well fields to behave uniformly. For example, Bogøgård had a small change in sulfate compared to a large drawdown (Figure 5, Figure 6), thereby indicating that it is not solely abstraction and a changed potentiometric surface that determine groundwater quality-well construction and well screen placing can also affect it (Baba and Ayyildiz, 2006). The correlation between drawdown and sulfate shows variance among the observations (Figure 5), one of the reasons for which could be multiple processes occurring at the same time within the same well field. At the Bogøgård well field, the concentration of water quality parameters differed between the wells, and between two periods, we observed both increases and decreases in different parameters between different wells, for example in sulfate concentration (Table 3). Table 3 reveals that the sulfate concentration increased by $37 \%$ in well 1 and decreased by $50 \%$ in well 2 , between the same periods within the well field. Furthermore, sulfate concentrations differ between the wells (79 to $239 \mathrm{mg} / \mathrm{L}$ in the second period), indicating that they abstract 
371 different types of water. Overall, sulfate concentration for the combined water from the well field

372 increased by $18 \%$. Measuring the changed water quality in the well field mix can be masked by changes in

373 individual wells. Hence, we can expect a varied aquifer response to abstraction that depends also on the

374 distribution of pumping rates between the wells and other factors, and it is important to acknowledge that

375 the analysis based on combined water from a well field does not explain specific changes or processes for

376 individual wells.

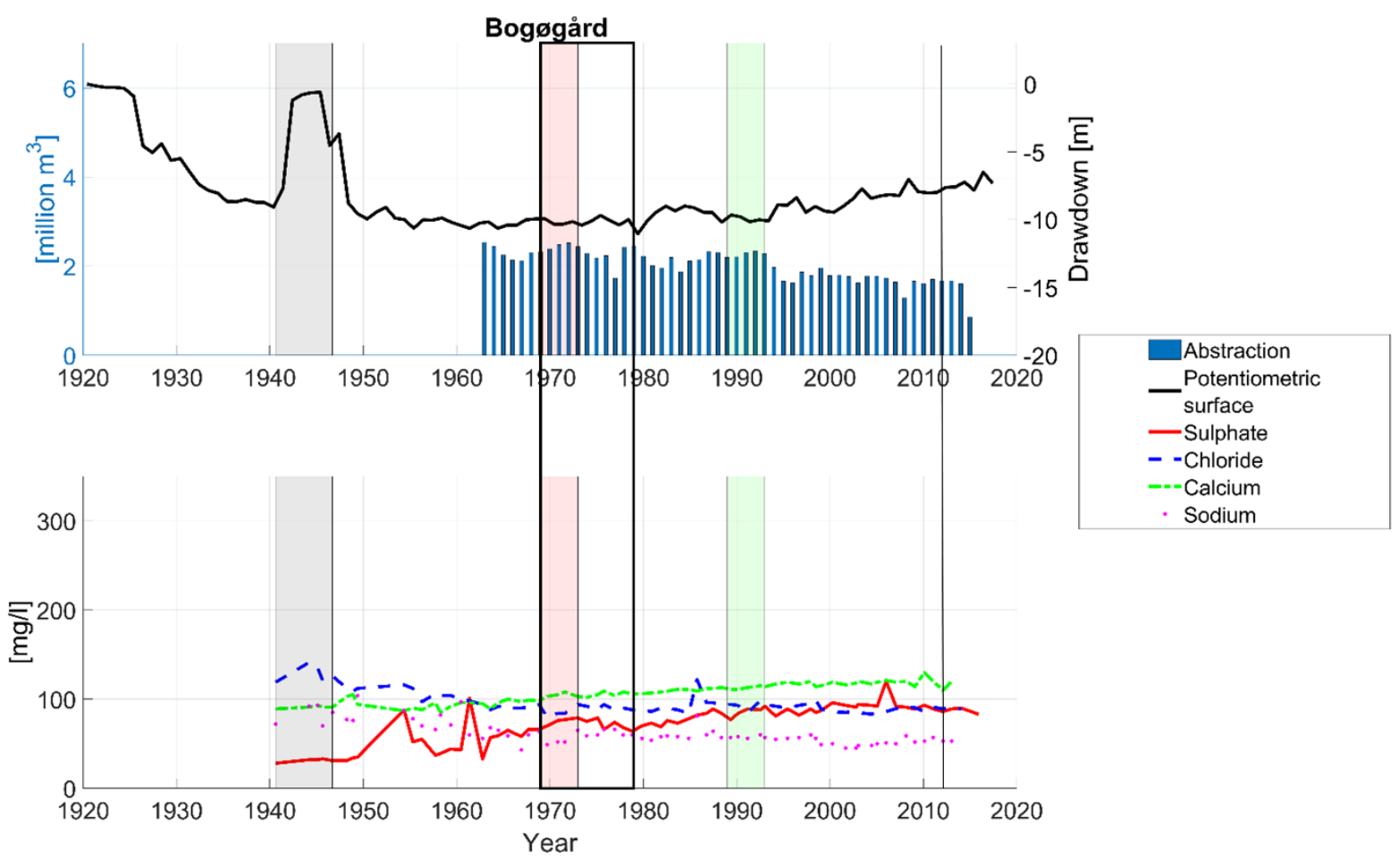

378 Figure 6: Sulfate, chloride, calcium, and sodium concentrations plotted with the potentiometric surface and abstraction for

379 Bogøgård well field, which has a relatively low change in sulfate compared to a relatively large drawdown. The hatched

380 areas refer to the periods compared: Grey is the first period, red is the maximum abstraction period and green is 20 


\begin{tabular}{|c|c|c|c|c|c|c|c|c|}
\hline \multirow{2}{*}{$\begin{array}{l}\text { Wells (DGU no.) } \\
\text { Period }\end{array}$} & \multicolumn{2}{|c|}{ Well 1 (200.3147) } & \multicolumn{2}{|c|}{ Well 2 (200.3148) } & \multicolumn{2}{|c|}{ Well 3 (200.3043) } & \multicolumn{2}{|c|}{$\begin{array}{c}\text { Well field } \\
\text { (combined } \\
\text { water) }\end{array}$} \\
\hline & 1970s & 2012 & 1970s & 2012 & 1970s & 2012 & 1970s & 2012 \\
\hline Screen depth [m] & \multicolumn{2}{|c|}{$43-52$} & \multicolumn{2}{|c|}{$38-52$} & \multicolumn{2}{|c|}{$43-52$} & \multicolumn{2}{|c|}{$38-65$} \\
\hline Chloride (mg/L) & 64 & 43 & 50 & 96 & 40 & 62 & 88 & 91 \\
\hline Hydrogen-carbonate (mg/L) & 357 & 362 & 363 & 342 & 339 & 324 & 338 & 337 \\
\hline Sulfate (mg/L) & 95 & 130 & 152 & 79 & 106 & 94 & 73 & 86 \\
\hline Calcium (mg/L) & 121 & 130 & 131 & 110 & 106 & 110 & 105 & 120 \\
\hline Magnesium (mg/L) & 21 & 19 & 25 & 18 & 28 & 16 & 19 & 20 \\
\hline Sodium (mg/L) & 41 & 34 & 41 & 61 & 27 & 32 & 59 & 57 \\
\hline
\end{tabular}

\subsection{Defining a sustainable abstraction?}

Our results support the hypothesis that water abstraction from a confined aquifer induces a decrease in the potentiometric surface and changed water quality across multiple well fields. This awareness takes us one step closer to defining a new criterion for sustainable groundwater abstraction and aquifer deterioration, which should serve as part of the complex task of ensuring sustainable groundwater abstraction, including sufficient water for environmental uses (International River Foundation, 2007), the use of renewable energy sources (Flavin and Lenssen, 1994), the efficient use of resources (Giljum et al., 2008), and other considerations such as toxicity, acidification etc. (Laurent et al., 2012). Since sulfate is the most sensitive parameter responding to abstraction for the 28 well fields (Table 2), it was the most suitable indicator for quantifying aquifer deterioration at the investigated well fields. If the conditions/geology are different, e.g. more risk of saltwater intrusion or mobilization, or pyrite is absent in the ground, another parameter 
should be chosen. Accepting that groundwater abstraction will affect water quality leads to the following question: When is changed water quality unacceptable?

Unacceptable changes can be described by different approaches, which we in the following discussion will refer to as A, B and C. Firstly (A), water quality does not meet drinking water quality standards, e.g. sulfate concentrations above 250 mg/L (The Danish Nature Agency, 2018); secondly (B), trends in one or more parameters will exceed the water quality standard within an unacceptable timeframe; or thirdly (C), persistent increased water quality parameters are unacceptable, no matter the proximity to the threshold values, as a precaution for ecosystem changes and a general sign of human impacts on the aquifer. Additionally, a water utility that has made large investments in constructing pipe systems, waterworks, etc. will be very dependent on stable water quality for decades to come.

In terms of approach A, drinking water quality standards are defined to secure healthy water that looks clean and is without color, taste, or odor (The Danish Nature Agency, 2018). For example, sulfate can, depending on the concentration, result in a bitter taste and provoke a laxative effect (Călinescu et al., 2016). Sulfate is only removed by advanced water treatment (Darbi et al., 2003) and is usually not removed at waterworks in Denmark. The sulfate concentrations at the 28 well fields did not exceed drinking water quality standards during the maximum abstraction period; however, two well fields exceeded or came within $5 \mathrm{mg} / \mathrm{L}$ of the threshold after the maximum abstraction period (Egholm and Vardegård well fields, SI. D). At Egholm well field, abstraction decreased after 1980, and Vardegård well field was closed in 2010 due to the presence of nickel.

Definitions B \& C are precautionary approaches to defining unacceptable changes. By studying the time series and defining unsustainable changes in sulfate concentrations as a 'minimum five observations of the initial concentration plus $20 \mathrm{mg} / \mathrm{L}^{\prime}$, then 26 out of 28 well fields experience aquifer deterioration at some point before 1995. If unsustainable changes in sulfate concentration were defined as a 'minimum of 10 observations of the initial concentration plus $50 \mathrm{mg} / \mathrm{L}^{\prime}, 13$ well fields experienced aquifer deterioration 
420 before 1995. Generally, sulfate increased for a number of years and peaked sometime after high

421 abstractions, after which it stabilized or decreased slowly.

\section{4.5.1 Recent developments at the 28 well fields}

423 Analyzing the sustainability of recent abstractions at the 28 well fields shows stable or slightly decreased 424 sulfate concentrations after 1995 (Figure 7.a). The abstraction peaked in 1982 and the average drawdown 425 was largest in 1978 for the 28 well fields (Figure 7.b). The decreased water abstraction since 1995 appears 426 to have resulted in an increased potentiometric surface and, after some years, stable water quality 427 parameters. Hence, decreased abstraction has alleviated aquifer deterioration in the 28 well fields 428 supplying water to Copenhagen, and so today the abstraction seems to be sustainable in terms of water 429 quality related to potentiometric surface drawdown. Since nitrate is a potential oxidant of pyrite it could be 430 interesting to look further into nitrate leaching and sulfate concentrations (Jessen et al., 2016; Jørgensen et 431 al., 2009). 

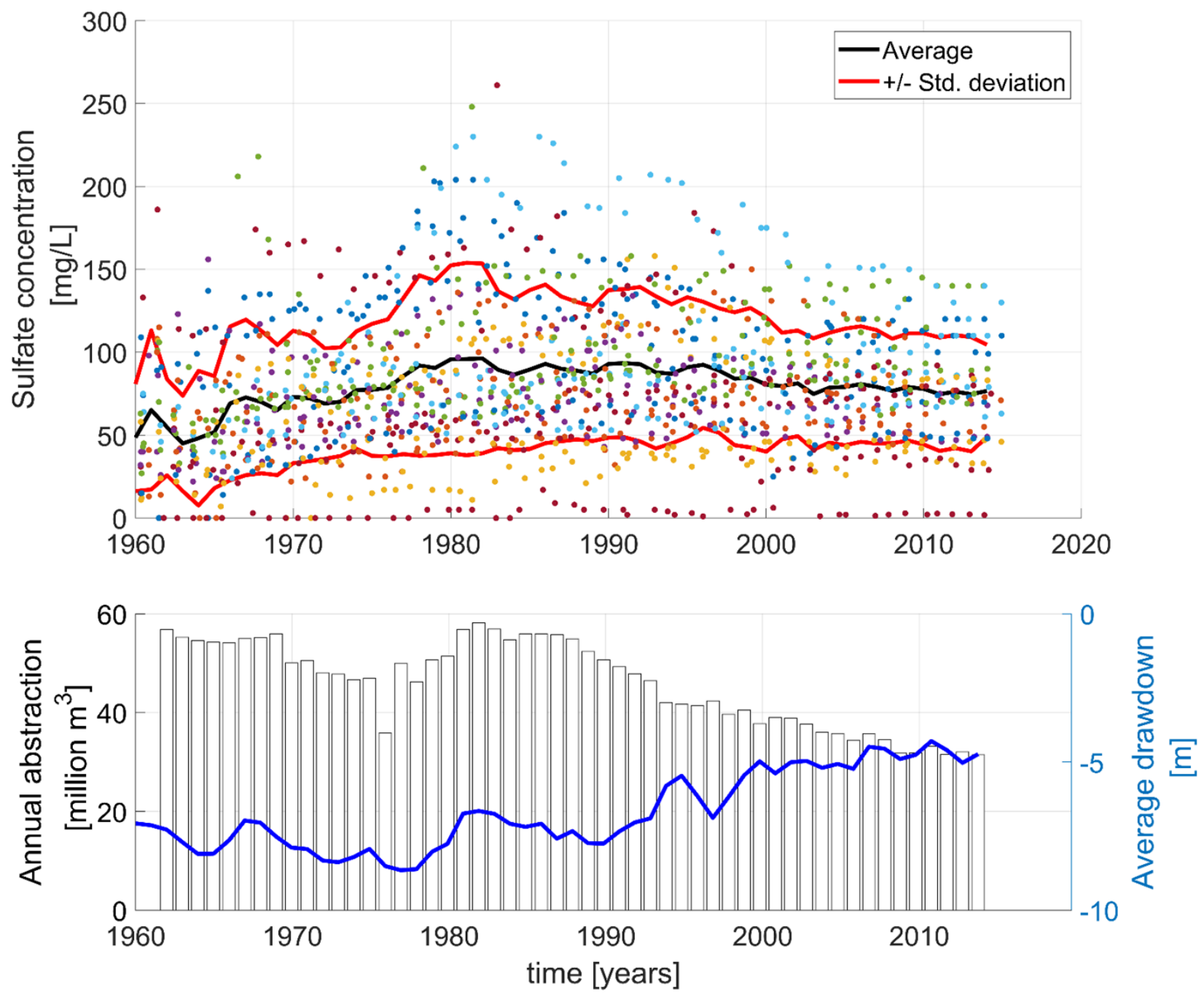

433

434

435

436

437

438

439

440

Figure 7: a) Sulfate concentrations from 1960-2015 for the 28 well fields (represented by different colors). The black line is the average of all sulfate concentrations within each year. The red lines represent $+/-$ std. dev. b) is the total water abstraction since 1962- and the average drawdown at the well fields- at the 28 well fields.

\section{Conclusions}

Long-term trends in water quality parameters were investigated, using a large dataset of 3,389 water quality samples and more than 10000 potentiometric surface observations for 28 well fields from 1940 to 2015. The analysis enabled us to identify changes in potentiometric surface and water quality over decades and provided valuable information on evaluating sustainable groundwater abstraction: 
- Long-term abstraction at 28 well fields resulted in decreased potentiometric surface at all well fields ( 2 to $14 \mathrm{~m}$ ), when comparing the initial potentiometric surface observation with the average potentiometric surface for the maximum abstraction period.

- Pyrite oxidation was the main process affecting long term water quality in the studied well fields, as observed in increased sulfate and calcium concentrations.

- The long-term patterns between potentiometric surface and water quality were significant for sulfate and calcium, with increased concentrations for 25 and 24 out of 27 well fields, respectively, when comparing the first period with the maximum abstraction period. There is no clear pattern between the potentiometric surface and the parameters chloride and magnesium, where equal amounts of well fields experience increased or decreased concentrations. However, sodium concentrations decreased for 23 out of 27 well fields.

- If we define sustainable groundwater abstraction as fewer than five observations of the initial sulfate concentration plus $20 \mathrm{mg} / \mathrm{L}, 26$ out of 28 well fields show indications of unsustainable abstraction before 1995. After 1995, the well fields generally show stable concentrations of water quality parameters or slightly decreased concentrations and the groundwater abstraction at 24 out of 28 well fields appear to be sustainable.

- Sulfate concentration had different delay periods from the maximum abstraction period, and the best correlation between increased drawdown and increased sulfate concentration was found for a 20-year delay in sulfate response.

\section{Acknowledgement: We would like to thank Kristian Bitsch and Jörg Schullehner for guidance and} discussions of the results and progress. This study is conducted at the Department of Environmental Engineering at Technical University of Denmark in collaboration with Hovedstadsområdets 
Forsyningsselskab, VandCenter Syd and Aarhus Vand. The work is part of an industrial PhD program, funded by the industrial partners and Innovation Fund Denmark.

\section{References}

Andersen, M.S., Larsen, F., Postma, D., 2001. Pyrite oxidation in unsaturated aquifer sediments. Reaction stoichiometry and rate of oxidation. Environ. Sci. Technol. 35, 4074-4079.

https://doi.org/10.1021/es0105919

Anderson, M.P., Woessner, W.W., Hunt, R.J., 2015. Applied groundwater modelling. Simulation of flow and advective transport., Second Edi. ed. Elsevier.

Appelo, C.A.., Postma, D., 2005. Geochemistry, groundwater and pollution, 2. ed. A.A. Balkema Publishers, Leiden.

Appelo, C.A.J., 1994. Cation and proton exchange, $\mathrm{pH}$ variations, and carbonate reactions in a freshening aquifer. Water Resour. Res. 30, 2793-2805. https://doi.org/10.1029/94WR01048

Baba, A., Ayyildiz, O., 2006. Urban Groundwater Pollution in Turkey - A National Review of Urban Groundwater Quality Issues. Urban Groundw. Manag. Sustain. 93-110. https://doi.org/10.1007/1-40205175-1_7

Bare, J.C., Hofstetter, P., Pennington, D.W., Haes, H. a. U., 2000. Midpoints versus endpoints: The sacrifices and benefits. Int. J. Life Cycle Assess. 5, 319-326. https://doi.org/10.1007/BF02978665

Barnaby, F., 1987. Our Common Future: The "Brundtland" Report. R. Swedish Acad. Sci. 16, 217-218.

Bauer-Gottwein, P., Gondwe, B.R.N., Charvet, G., Marín, L.E., Rebolledo-Vieyra, M., Merediz-Alonso, G., 2011. Review: The Yucatán Peninsula karst aquifer, Mexico. Hydrogeol. J. 19, 507-524. https://doi.org/10.1007/s10040-010-0699-5

Boulay, A.M., Bare, J., Benini, L., Berger, M., Lathuillière, M.J., Manzardo, A., Margni, M., Motoshita, M., Núñez, M., Pastor, A.V., Ridoutt, B., Oki, T., Worbe, S., Pfister, S., 2017. The WULCA consensus characterization model for water scarcity footprints: assessing impacts of water consumption based on available water remaining (AWARE). Int. J. Life Cycle Assess. 1-11. https://doi.org/10.1007/s11367-0171333-8

Bryan, E., Meredith, K.T., Baker, A., Post, V.E.A., Andersen, M.S., 2016. Island groundwater resources, impacts of abstraction and a drying climate: Rottnest Island, Western Australia. J. Hydrol. 542, 704-718. https://doi.org/10.1016/j.jhydrol.2016.09.043

Călinescu, O., Marin, N.M., Ioniță, D., Pascu, L.F., Tudorache, A., Surpățeanue, G., Badea, I.A., Aboul-Enein, H.Y., 2016. Selective removal of sulfate ion from different drinking waters. Environ. Nanotechnol. Monit. Manag. 6, 164-168. https://doi.org/10.1016/j.enmm.2016.10.004 
Darbi, A., Viraraghavan, T., Jin, Y.-C., Braul, L., Corkal, D., 2003. Sulfate removal from water. Water Qual. Res. J. Canada 38, 169-182.

Flavin, C., Lenssen, N., 1994. Reshaping the electric power industry. Energy Policy 22, 1029-1044. https://doi.org/10.1016/0301-4215(94)90017-5

Freeze, R.A., Cherry, J.A., 1979. Groundwater. Prentice-Hall.

Gejl, R.N., Bjerg, P.L., Henriksen, H.J., Hauschild, M.Z., Rasmussen, J., Rygaard, M., 2018. Integrating groundwater stress in life-cycle assessments - An evaluation of water abstraction. J. Environ. Manage. 222. https://doi.org/10.1016/j.jenvman.2018.05.058

Giljum, S., Behrens, A., Hinterberger, F., Lutz, C., Meyer, B., 2008. Modelling scenarios towards a sustainable use of natural resources in Europe. Environ. Sci. Policy 11, 204-216. https://doi.org/10.1016/j.envsci.2007.07.005

Gleeson, T., Wada, Y., Bierkens, M.F.P., van Beek, L.P.H., 2012. Water balance of global aquifers revealed by groundwater footprint. Nature 488, 197-200. https://doi.org/10.1038/nature11295

Hansen, B., Dalgaard, T., Thorling, L., Sørensen, B., Erlandsen, M., 2012. Regional analysis of groundwater nitrate concentrations and trends in Denmark in regard to agricultural influence. Biogeosciences 9, 32773286. https://doi.org/10.5194/bg-9-3277-2012

Hansen, B., Mossin, L., Ramsay, L., Thorling, L., Ernstsen, V., Jørgensen, J., Kristensen, M., 2009. Kemisk grundvandskortlægning. Geo-vejledning 6. GEUS, Copenhagen.

Hansen, B., Thorling, L., Dalgaard, T., Erlandsen, M., 2011. Trend reversal of nitrate in Danish groundwater A reflection of agricultural practices and nitrogen surpluses since 1950. Environ. Sci. Technol. 45, 228-234. https://doi.org/10.1021/es102334u

He, S., Wu, J., 2018. Hydrogeochemical Characteristics, Groundwater Quality, and Health Risks from Hexavalent Chromium and Nitrate in Groundwater of Huanhe Formation in Wuqi County, Northwest China. Expo. Health. https://doi.org/10.1007/s12403-018-0289-7

Henriksen, H.J., Refsgaard, J.C., 2013. Sustainable groundwater abstraction - a review report. Danmarks og Grønlands Geologiske Undersøgelse Rapport. 2013/30. GEUS, Copenhagen.

Henriksen, H.J., Troldborg, L., Højberg, A.L., Refsgaard, J.C., 2008. Assessment of exploitable groundwater resources of Denmark by use of ensemble resource indicators and a numerical groundwater-surface water model. J. Hydrol. 348, 224-240. https://doi.org/10.1016/j.jhydrol.2007.09.056

International River Foundation, 2007. The Brisbane Declaration. pp. 1-7.

Jakobsen, P.R., Rohde, M.M., Sheldon, E., 2017. Structures and stratigraphy of Danian limestone, eastern Sjælland, Denmark. Geol. Surv. Denmark Greenl. Bull. 38, 21-24. 
Jensen, T.F., Larsen, F., Kjøller, C., Larsen, J.W., 2003. Nickel release from oxidation of pyrite caused by wells that are not air tight /pumping. (Nikkelfrigivelse ved pyritoxidation forårsaget af barometerånding / pumpning). The Danish Nature Agency, Copenhagen.

Jessen, S., Postma, D., Thorling, L., Müller, S., Leskelä, J., Engesgaard, P., 2016. Decadal variations in groundwater quality: A legacy from nitrate leaching and denitrification by pyrite in a sandy aquifer. Water Resour. Res. 1-24.

Jørgensen, C.J., Jacobsen, O.S., Elberling, B., Aamand, J., 2009. Microbial oxidation of pyrite coupled to nitrate reduction in anoxic groundwater sediment. Environ. Sci. Technol. 43, 4851-4857. https://doi.org/10.1021/es803417s

Knudsen, C., 1999. Nickel in groundwater. Copenhagen, Køge bay and area of Stevns. (Nikkel i grundvand. København, Køge Bugt og Stevns området). GEUS, Copenhagen.

Larsen, F., Kjøller, C., 2009. Arsenic in Danish groundwater and drinking water (Arsen i dansk grundvand og drikkevand). The Danish Nature Agency, Copenhagen.

Larsen, F., Postma, D., 1997. Nickel mobilization in a groundwater well field: Release by pyrite oxidation and desorption from manganese oxides. Environ. Sci. Technol. 31, 2589-2595. https://doi.org/10.1021/es9610794

Laurent, A., Olsen, S.I., Hauschild, M.Z., 2012. Limitations of carbon footprint as indicator of environmental sustainability. Environ. Sci. Technol. 46, 4100-4108. https://doi.org/10.1021/es204163f

Li, P., Qian, H., 2018. Water resources research to support a sustainable China. Int. J. Water Resour. Dev. 34, 327-336. https://doi.org/10.1080/07900627.2018.1452723

Loftis, J.C., 1996. Trends in groundwater quality. Hydrol. Process. 10, 335-355.

https://doi.org/10.1002/(SICI)1099-1085(199602)10:2<335::AID-HYP359>3.0.CO;2-T

Luczaj, J.A., Maas, J., Hart, D.J., Odekirk, J., 2017. Aquifer Drawdown and Recovery in the Northeast Groundwater Management Area, Wisconsin, USA : A Century of Groundwater Use. Geosciences 11. https://doi.org/10.3390/geosciences7010011

Margat, J., van der Gun, J., 2013. Groundwater withdrawal and use, in: Groundwater around the World: A Geographic Synopsis. Taylor and Francis, London, U. K, p. 376.

Miao, Z., Brusseau, M.L., Carroll, K.C., Carreón-Diazconti, C., Johnson, B., 2013. NIH Public Access. Sulfate Reduct. Groundw. Charact. Appl. Remediat. 34, 539-550. https://doi.org/10.1007/s10653-011-94231.SULFATE

The Danish Nature Agency, 2018. Statutory Order on Water Quality and Supervision of Water Supply Plants. (BEK 1068:2018. Bekendtgørelse om vandkvalitet og tilsyn med vandforsyningsanlæg). Copenhagen.

Mosthaf, K., Brauns, B., Fjordbøge, A.S., Rohde, M.M., Kerrn-Jespersen, H., Bjerg, P.L., Binning, P.J., Broholm, M.M., 2018. Conceptualization of flow and transport in a limestone aquifer by multiple dedicated hydraulic and tracer tests. J. Hydrol. 561, 532-546. https://doi.org/10.1016/j.jhydrol.2018.04.011 
564 Nordstrom, D.K., 2002. Worldwide Occurence of Arsenic in Ground Water. Science 296, 2143-2145.

565 https://doi.org/10.1007/b101867

566 Pfister, S., Koehler, A., Hellweg, S., 2009. Assessing the Environental Impact of Freshwater Consumption in 567 Life Cycle Assessment. Environ. Sci. Technol. 43, 4098-4104.

568 Postma, D., Larsen, F., Minh Hue, N.T., Duc, M.T., Viet, P.H., Nhan, P.Q., Jessen, S., 2007. Arsenic in 569 groundwater of the Red River floodplain, Vietnam: Controlling geochemical processes and reactive 570 transport modeling. Geochim. Cosmochim. Acta 71, 5054-5071. https://doi.org/10.1016/j.gca.2007.08.020

571 Schullehner, J., Hansen, B., Thygesen, M., Pedersen, C.B., Sigsgaard, T., 2018. Nitrate in drinking water and 572 colorectal cancer risk: A nationwide population-based cohort study. Int. J. Cancer 143, 73-79.

573 https://doi.org/10.1002/ijc.31306

574 Smakhtin, V., Revenga, C., Döll, P., 2004. A Pilot Global Assessment of Environmental Water Requirements 575 and Scarcity. Assessment 29, 307-317. https://doi.org/10.1080/02508060408691785

576 Trowsdale, S. a., Lerner, D.N., 2003. Implications of flow patterns in the sandstone aquifer beneath the 577 mature conurbation of Nottingham (UK) for source protection. Q. J. Eng. Geol. Hydrogeol. 36, 197-206. 578 https://doi.org/10.1144/1470-9236/02-017

579 Vangkilde-Pedersen, T., Mielby, S., Jakobsen, P.R., Hansen, B., Iversen, C.H., Nielsen, A.M., 2011. Mapping 580 of limestone aquifers (Kortlægning af kalkmagasiner). Geo-vejledning 8. GEUS, Copenhagen.

581 Whittemore, D.O., Butler, J.J., Wilson, B.B., 2016. Assessing the major drivers of water-level declines: new 582 insights into the future of heavily stressed aquifers. Hydrol. Sci. J. 61, 134-145.

583 https://doi.org/10.1080/02626667.2014.959958

584 Zhang, Y.C., Prommer, H., Broers, H.P., Slomp, C.P., Greskowiak, J., Grift, B. Van Der, 2013. Model-based 585 integration and analysis of biogeochemical and isotopic dynamics in a nitrate-polluted pyritic aquifer. 586 Environ. Sci. Technol. 47, 10415-10422. 